\title{
Plasma spheroidisation of high melt point materials on example of tungsten
}

\section{Sferoidyzacja plazmowa materiałów o wysokiej temperaturze topienia na przykładzie wolframu}

\section{Abstract}

Particle shape and size, density and distribution are important characteristics of the powders processed by additive manufacturing processes e.g. Selective Laser Melting (SLM) or Electron Beam Melting (EBM). Spherical shape of powder particles allows to stably carrying out the process and affects also the manufactured objects properties. Desired morphology of the powder can be achieved by powder manufacturing process or by additional treatment of the non-spherical powders. This paper is dedicated to study spheroidization of tungsten powder by Atmosphere Plasma Spraying (APS). Influence of APS process parameters and preliminary powder treatment has been analysed. Scanning electron microscopy (SEM) was used for the evaluation of shape, size and distribution of post-processed powder particles.

Keywords: powders spheroidisation, plasma spheroidisation, additive manufacturing technologies

\section{Streszczenie}

Kształt oraz wielkość cząstek, gęstość oraz rozkład są istotnymi cechami charakterystycznymi proszków przetwarzanych za pomocą technologii przyrostowych n.p. selektywnej laserowej mikrometalurgii proszków (SLM) lub elektronowej mikrometalurgii proszków (EBM). Sferyczny kształt cząstek proszku umożliwia stabilne prowadzanie w/w procesów oraz wpływa na własności wytwarzanych nimi obiektów. Oczekiwana morfologia proszku może być osiągnięta za pomocą jego procesu wytwarzania, jak również poprzez dodatkową obróbkę proszków niesferycznych. Artykuł jest poświęcony badaniom sferoidyzacji proszku wolframu za pomocą natryskiwania plazmowego (APS). Został przeanalizowany wpływ parametrów procesu oraz wstępnej obróbki proszku. Do oceny kształtu, wielkości i dystrybucji otrzymywanych cząstek proszku została zastosowana skaningowa mikroskopia elektronowa (SEM).

Słowa kluczowe: sferoidyzacja proszków, sferoidyzacja plazmowa, generatywne technologie wytwarzania

\section{Introduction}

According to ASTM F2792-10 "Additive Manufacturing is a process of joining materials to make objects from 3D model data, usually layer upon layer, as opposed to subtractive manufacturing methodologies [1]". It is a relatively new group of technologies. First processes, which were applied for rapid prototyping, appeared in ' 80 of the XX century. During the last 25 years AM marked grew and today it is worth 2 milliard of dollars, including materials, devices and services. Forecasts expect continued growth up to 10.8 milliards in 2021 [2,3]. Due to the specific character of the AM technologies, the processed metallic alloys have to fulfil several requirements specified by technology [4], regarding:

- physical properties, such as density and absorption, thermal capacity and specific heat capacity, latent heat of fusion and melting temperature determine the melt enthalpy of the metal,

- chemical composition, which defines behaviour of multicomponent alloy, i.e. after-affects like shrinkage or wettability).

Additional set of properties is linked to the form of those metallic components. Particle size distribution, particle morphology and bulk density (synonyms - apparent or relative density) of the metal powders have a significant influence on carrying out the AM processes and quality of the manufactured objects. For AM powder processing technologies it is more preferable to use powder with spherical or spheroidal shape (morphology) of the particles which leads to bigger bulk density and better flowability [ $5 \div 10]$. The other important process parameter, which influences the quality of the objects, is layer thickness.

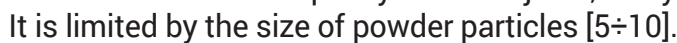

There are five basic groups of techniques of metal powder manufacturing [11]:

(a) mechanical methods (milling, crushing, breaking, machining), which use a mechanical crushing of raw material in the solid state,

(b) physicomechanical methods (spraying, granulation), which change a solid to liquid and back to a solid state,

(c) physical methods (evaporation and condensation), where physical phenomena are used for powder production,

(d) chemical methods (reduction or dissociation of oxides and other compounds, intergranular corrosion, hydrogenation and dehydrogenation),

(e) physicochemical methods (reduction of aqueous solutions of salt with hydrogen; electrolysis of brines or molten salts; synthesis and dissociation of carbonyls; sol-gel) combine chemical reactions with physical phenomena.

Most of those methods result in powders with irregular shape of particles, which lead to low apparent density

Mgr inż. Karol Kobiela, mgr inż. Irina Smolina, dr inż. Mariusz Frankiewicz, prof. dr hab. inż. Edward Chlebus - Wydział Mechaniczny Politechniki Wrocławskiej. 
and high porosity of the final product [12]. Spheroidal or spherical powder particles morphology can be achieved by atomisation with a gas stream or dissipation of carbonyls [11]. Within the powder atomisation processes, to obtain high quality powders, two main groups might stand out: (1) spraying of gas and liquid; (2) spraying with use of centrifugal force and the spraying with rotating electrode. Processes that allow the manufacturing of dense, fine spherical particle powders, that exhibit a good flowability, are gas atomisation [17], plasma atomization [13,18,21], rotating disk atomization [19], and hybrid atomisation [20]. Mentioned processes, e.g. plasma atomisation, might be applied for powder manufacturing as well as for reshaping and resizing of powder particles $[5,6]$. In Poland one of the most notable works in this field was done at Military University of Technology in Warsaw [5,6,12,14,15].

The main objective of this study is an evaluation of the possibilities of applyingan atmospheric plasma spraying (APS) for spheroidisation of irregular tungsten powder particles. The influence of preliminary treated powder (milling and/or sieving), flight path and plasma power on the result of the spheroidisation process has been evaluated.

\section{Experiment}

\section{Process conditions}

Tungsten powder spheroidisation process was carried out on a robotized plasma spray station. The scheme of the process was shown on figure 1. Spheroidisation process was conducted in a vertical layout system, where the process chamber includes a reservoir with a cooling medium (distilled water) with a vertical tube, wherein the outlet during process plasma gun is directed co-axial to the tube. Gunto-water distance has been regulated thanks to the modular design where the tube can be easily changed. Powder was transferred to the plasma torch by an argon gas and it has been injected radially to the axis of plasma spray flow.

After spheroidisation process, tungsten has been dried for $8 \mathrm{~h}$ at $100^{\circ} \mathrm{C}$.

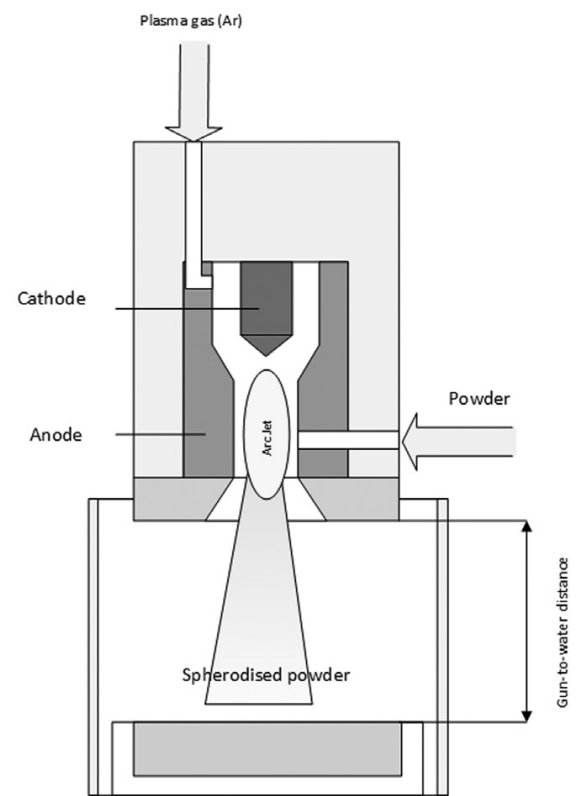

Fig. 1. The scheme of the atomisation of the irregular powders approach by APS

Rys. 1. Schemat procesu atomizacji proszków o nieregularnych ziarnach za pomocą APS

\section{Material}

Technical clear tungsten powder with irregular shape of particles was used for this study. Experiments were carried out on two types of tungsten powder (Fig. 2).

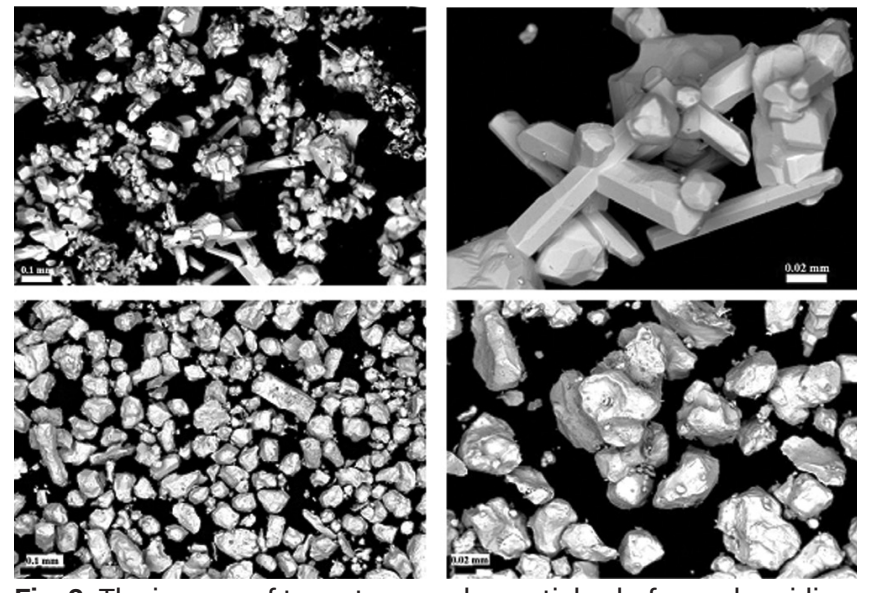

Fig. 2. The images of tungsten powder particles before spheroidization process: in initial state (as-received) (a), (b); after milling and sieving (c) and (d); SEM

Rys. 2. Obrazy cząstek proszku wolframu przed procesem sferoidyzacji: w stanie wejściowym (dostawy) (a), (b); po zmieleniu i przesianiu (c) oraz (d); SEM

The first type of processed material was untreated (as-delivered) tungsten powder (Fig. 2a, b). The second material had been previously pre-treated by mechanical milling carried out in a planetary mono mill Fritsch Pulverisette 6 and followed by sieving under fraction $63 \mu \mathrm{m}$ (Fig. $2 \mathrm{c}$, d). For the vial and grinding medium $20 \mathrm{~mm} \mathrm{ZrO}$ balls have been used. It was chosen in respect to milling station manufacturer suggestions [16].

Powder morphology (shape and size) was analysed using SEM ZEISS EVO MA25 with SE, BSE and EDX detectors. Sieving of the tungsten powder was done in a vibratory sieve shaker Fritsch with a set of sieves according to standard requirements (PN-EN 24497, ISO 4497).

\section{Results and Discussion}

\section{Effect of the plasma power on spheroidisation}

First parameter, which was tested for defining optimal parameters for obtaining spherical/spheroidal particles, is the power of the plasma stream. Tests were provided with plasma power. $30,32,34$ and $35 \mathrm{~kW}$. Tests were performed on milled and sieved to under $63 \mu \mathrm{m}$ fracture tungsten powder. Gun-to-water distance was chosen as $750 \mathrm{~mm}$ between the head of plasma torch and cooler (container with cold water).

Quantity of tungsten powder particles with spherical shape was around $90 \%$. Most of those particles size was in the range between $40-60 \mu \mathrm{m}$. Small defects on the surface of particles, like pores or cracks, can be seen (Fig. 3).
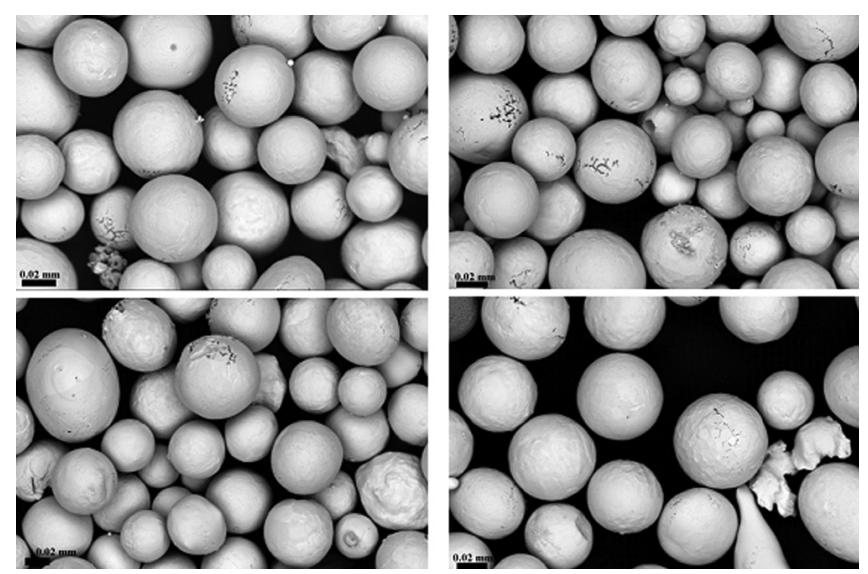

Fig. 3. The images of the tungsten powder particles after spheroidisation process carried out with different power plasma power. $30 \mathrm{~kW}(\mathrm{a}) ; 32 \mathrm{~kW}$ (b); $34 \mathrm{~kW}$ (c) and $35 \mathrm{~kW}$ (d); SEM

Rys. 3. Obrazy cząstek proszku wolframu po procesie sferoidyzacji przeprowadzonej przy różnych wartościach mocy plazmy: 30 kW (a); 32 (b); 34 kW (c) oraz 35 kW (d); SEM 
Important issue that quantity of spherical particles is decreasing with decreasing plasma power from $35 \mathrm{~kW}$ to 32 and $30 \mathrm{~kW}$. At the same time the quantity of defective particles or non-spheroidised particles are increased, especially during the process at $30 \mathrm{~kW}$ (Fig. 4).

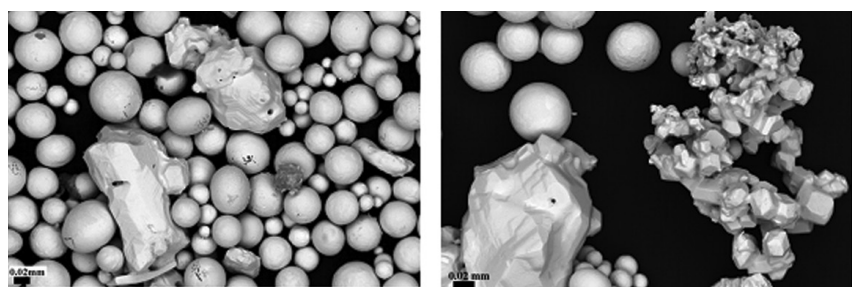

Fig. 4. Images of defected particles: particle with irregular shape (left image); agglomerated (sintered) smal particles emerging in process at $30 \mathrm{~kW}$ (right image); SEM

Rys. 4. Obrazy zdefektowanych cząstek proszku: cząstki o nieregularnym kształcie (po lewej); zaglomerowane (spieczone) niewielkie cząstki pojawiające się w procesie przy 30 kW (po prawej); SEM

Some trace particles were observed, which contain Co, $\mathrm{Cr}, \mathrm{Fe}$ and $\mathrm{O}$ and possibly appeared during process due to the contact of hard material (tungsten) with surfaces in the process chamber. The other reason for the appearing trace elements is the possibility of the presence of other particles from previous experiments with other materials.

Influence of thermal power in the range of 30-35 kW on the size of particles of preliminary treated tungsten powder was not observed in this experiment.

\section{Effect of preliminary treatment of the powder on the size and spheroidisation}

For this test samples from untreated (as-delivered) powder and powder after milling and sieving under $63 \mu \mathrm{m}$ fraction were prepared. Two kinds of tests were provided at $35 \mathrm{~kW}$ and at $30 \mathrm{~kW}$. Both batches of samples were processed at 35 and $30 \mathrm{~kW}$ as presented in figure 5 .

Spheroidisation of untreated tungsten powder (as-received) is characterized by low efficiency. It had an ultimately small quantity of spheroidised particles. Very few of them seemed to be on the initial state of spheroidisation. However, most are still rectangular, the smallest one created agglomerations.
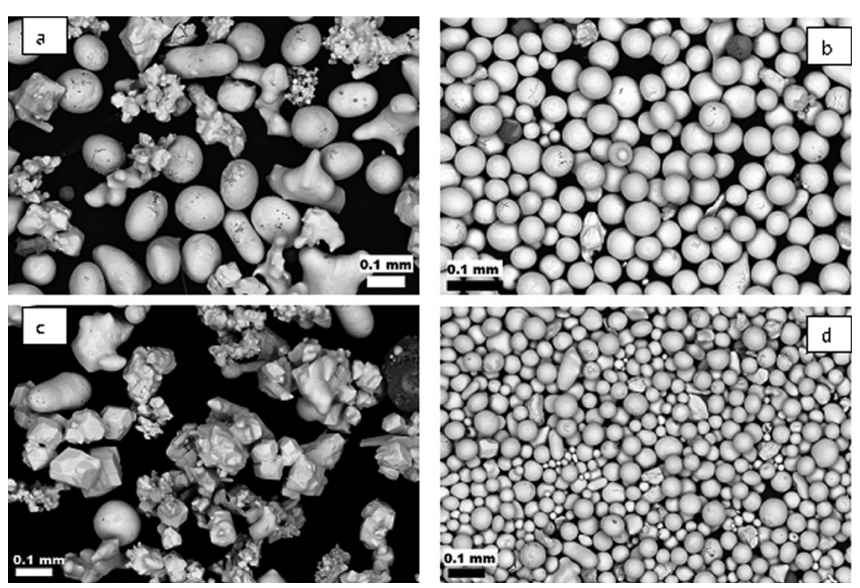

Fig. 5. Images of the tungsten powder after plasma spheroidisation: received at $35 \mathrm{~kW} \mathrm{(a)} \mathrm{and} 30 \mathrm{~kW}$ (c) processes without preliminary treatment; received at $35 \mathrm{~kW}$ (b) and $30 \mathrm{~kW}$ (d) processes after preliminary milling and sieving; SEM

Rys. 5. Obrazy proszku wolframu po sferoidyzacji plazmowej: uzyskane w procesach przy $35 \mathrm{~kW}$ (a) oraz 30 kW (b) bez obróbki wstępnej; uzyskane w procesach przy 35 kW (a) oraz 30 kW (b) po wstępnym mieleniu i przesianiu; SEM

This occurrence was observed for both samples of as-received tungsten powder. Which means that for a rectangular powder the difference in thermal power of $5 \mathrm{~kW}$ does not play an important role. Process of spheroidisation is unsatisfied, and most particles remained in the previous shape or even create conglomerations. Preliminary treated powder (by milling and sieving) allowed to obtain satisfying results even at $30 \mathrm{~kW}$ thermal power of plasma.

Effect of the gun-to-water surface distance on spheroidisation

This kind of test provided experiments on the gun-towater distance. Three distances were chosen: 250, 750 and $1000 \mathrm{~mm}$. Experiments were done at 17 and $30 \mathrm{~kW}$. Also, the synergetic effect of gun-to-water distance (for 750 and $1000 \mathrm{~mm}$ ) and preliminary treatment of powder (as-delivered or after milling and following sieving) was tested. Parameters and view of particles are summarized in table I.

Table I. Influence of spheroidization process parameters (gun-to-water distance, plasma power and preliminary treatment of powder) on the treated powder grains shape

Tablica I. Wpływ parametrów procesu sfereoidyzacji (odległości pomiędzy palnikiem a powierzchnią zbiornika przechwytującego proszek, mocy plazmy oraz wstępnej obróbki proszku) na kształt ziaren przetwarzanego proszku

\begin{tabular}{|c|c|c|c|}
\hline $\begin{array}{l}\text { Gun-to-water } \\
\text { distance }[\mathrm{mm}]\end{array}$ & $\begin{array}{l}\text { Images of processed powder particles after spheroidisation } \\
\text { with different parameters }\end{array}$ & $\begin{array}{l}\text { Plasma Power } \\
{[\mathrm{kW}]}\end{array}$ & State of powder \\
\hline 250 & & 17 & As-received \\
\hline 250 & & 30 & As-received \\
\hline 1000 & & 30 & As-received \\
\hline
\end{tabular}


Table II. Table I (cont) Influence of spheroidization process parameters (gun-to-water distance, plasma power and preliminary treatment of powder) on the treated powder grains shape

Tablica II. Tablica I (cd.) Wpływ parametrów procesu sfereoidyzacji (odległości pomiędzy palnikiem a powierzchnią zbiornika przechwytującego proszek, mocy plazmy oraz wstępnej obróbki proszku) na kształt ziaren przetwarzanego proszku

\begin{tabular}{|l|l|l|c|}
\hline $\begin{array}{c}\text { Gun-to-water } \\
\text { distance [mm] }\end{array}$ & $\begin{array}{l}\text { Images of processed powder particles after spheroidisation } \\
\text { with different parameters }\end{array}$ & $\begin{array}{c}\text { Plasma Power } \\
{[\mathrm{kW}]}\end{array}$ & State of powder \\
\hline & & & 30 \\
& &
\end{tabular}

\section{Conclusions}

Influence of plasma power. The high plasma power $(>30 \mathrm{~kW})$ is required for a sufficient spheroidisation process. The higher efficiency of this process is ensured by using prepared powder. milled and sieved under selected fraction. From the other side, the quantity of defected or non-spheroidised particles is increased, especially during the process at 30 $\mathrm{kW}$. Influence of plasma power in the range of 30-35 kW on the size of particles of preliminary treated tungsten powder was not observed in that experiment.

Influence of preliminary treatment of tungsten powder. Powder after sieving has an isolated fraction range. Also milling process unifies the powder. Both of those factors have an ultimate influence on the processing results. Both tests (at 30 and $35 \mathrm{~kW}$ ) showed unsatisfied (low-efficient) result of spheroidisation for untreated (as-received) tungsten powder.

The small gun-to-water distance $(250 \mathrm{~mm})$ gives particles higher kinetic energy at the water surface, in connection of this feature with the high power results in deformations of particles at contact with the water. The bigger gun-to-water distance $(1000 \mathrm{~mm})$ decreased the efficiency of the process.

\section{Acknowledgments}

This research was financially supported by the National Centre for Research and Development (No. PBS1/A5/12/2012).

\section{References}

[1] ASTM F2792-10. Standard Terminology for Additive Manufacturing Technologies.

[2] Scott J., Gupta N., Weber C., Newsome S., Wohlers T., Caffrey T., Additive Manufacturing: Status and Opportunities, Science and Technology Policy Institute, 2012.

[3] Wohlers T., Wohler's Report: Additive Manufacturing and 3D printing, State of the Industry, Wohler's Associates Inc., 2013.

[4] Khan M., Selective Laser Melting (SLM) of Gold (Au), PhD Thesis, Loughborough University, UK 2010.

[5] Majewski T., Badanie procesów modyfikacji plazmowej proszków W i Re oraz mieszanek W-Re, Biuletyn WAT, Vol. LX, Nr 2, 2011

[6] Majewski T., Dębski A., Badania procesu sferoidyzacji proszku wolframu i molibdenu w strumieniu plazmy, Biuletyn WAT, Vol. LVI, Nr 3, 2007

[7] Fauchais P., Montavon G., Bertrand G., From Powders to Thermally Sprayed Coatings, Journal of Thermal Spray Technology, 2010, Volume 19, Issue 1-2, pp. 56-80.

[8] Wrona A., Sejda-Leszczyńska K., Lis M., Czepelak M., Mazur J., Bilewska K., Woch M., Chmielarz A., Staszewski M., Osadnik M., Sferyczne proszki ze stopów renu z kobaltem i niklem, Rudy i Metale Nieżelazne, 2013, numer 12, s. 828-834.

[9] Woch M., Missol W., Lis M., Ksieżarek S., Badania Instytutu Metali Nieżelaznych nad wykorzystaniem renu w przetwórstwie metali nieżelaznych, Rudy i Metale Nieżelazne, 2011, numer 5, s. 266-271.

[10] Kurzynowski T., Chlebus E., Kużnicka B., Reiner J. Parameters in selective laser melting for processing metallic powders, Proceedings of SPIE - The International Society for Optical Engineering, 8239, art. no. 823914. ISBN: 978-081948882-4, doi: 10.1117/12.907292

[11] Leżański J., Proszki metali i wysokotopliwych faz. Metody wytwarzania, Wydawnictwa AGH, Kraków 1994.
[12] Majewski T., Investigation of W-Re-Ni Heavy Alloys Produced From Plasma Spheroidized Powders, Solid State Phenomena Vol. 199 (2013), pp 448-453. doi: 10.4028/www.scientific.net/SSP.199.448.

[13] Boulos M., Plasma power can make better powders, Metal Powder Report, Vol. 59, Issue 5, May 2004, P. 16-21. doi:10.1016/S00260657(04)00153-5.

[14] Majewski T., Modification of $W$ and Re Powders by Plasma Technique, Solid State Phenomena Vol. 165 (2010), pp. 130-135.

[15] Majewski T., Research of Spheroidization Processes of W-Re Powders, Solid State Phenomena Vol. 199 (2013), pp. 490-495.

[16] Planetary Mono Mill, Pulverisette 6. Access link http://www.asi-team.com/asi\%20team/fritsch/Fritsch\%20data/pulverisette6-1.pdf

[17] A. Lawley, Atomization: The Production of Metal Powders, MPIF, Princeton, NJ, USA, 1992.

[18] M. Entezarian, F. Allaire, P. Tsantrizos Ph.D., R. A. L. Drew Ph.D., Plasma atomization: A new process for the production of fine, spherical powders, JOM, Volume 48, Issue 6 (1996), pp 53-55.

[19] Huiping Li, Xucheng D.., Prediction of powder particle size during centrifugal atomisation using a rotating disk, Science and Technology of Advanced Materials, Volume 8, Issue 4, (2007), pp. 264-270.

[20] Minagawa K., Kakisawa H., Osawa Y., Takamori S., Halada K., Production of fine spherical lead-free solder powders by hybrid atomization, Science and Technology of Advanced Materials, Volume 6, Issues 3-4, April-May 2005, pp. 325-329.

[21] Wrona, A. Leszczyńska-Sejda, K. Lis, M. Benke, G. Czepelak, M. Anyszkiewicz, K. Mazur, J. Bilewska, K. Chmielarz, A. Woch, M. Staszewski, M. Osadnik, M. Orłowska-Buzek, Ł. Kozub, K. Gambal, P. Satora, W. Spherical powders of rhenium-based alloys with cobalt and nickel, Rudy i Metale Nieżelazne, R. 58/ 12 (2013), pp. 828-834. 